\title{
Comparison of the Effectiveness of Sling Exercise and McKenzie Exercise in Patients with Acute Cervical Whiplash Associated Disorder Following Rear-end Collision
}

\author{
Mo-Beom Jeong', Jae-Yun Kim², Dong-Woo Lee ${ }^{3}$ \\ ${ }^{1}$ Chung Yeon Oriental Medicine Clinic, Gwangju; ${ }^{2}$ Department of Occupational and Environmental Medicine, School of Medicine, Chosun University, \\ Gwangju; ${ }^{3}$ Department of Physical Therapy, Honam University, Gwangju, Korea
}

Purpose: This study compared the effectiveness of sling exercise and McKenzie exercise in patients with acute cervical whiplash associated disorder (WAD) caused by rear-end collision.

Methods: Thirty WAD patients were randomly assigned to one of three groups; a sling exercise (SE) group, a McKenzie exercise (McE) group, and a control group. Members of the SE and McE exercised three times a week for four weeks under the researcher's guidance. Three groups performed TENS treatment three times a week for four weeks. Diagnostic radiological equipment was used to measure whiplash injury. Visual analog scale (VAS), neck disability index (NDI), and range of motion (ROM) were used in this study.

Results: The three groups showed a significant pre-post treatment difference in measures of VAS and NDI $(p<0.05)$. The SE group showed a significant pre-post treatment difference in measures of flexion and extension changes compared to the McE and control group $(p<0.05)$. The SE group also showed significantly greater improvement in the VAS, NDI, and ROM changes than the control group $(\mathrm{p}<0.05)$.

Conclusion: These findings indicate that sling exercise is a stronger and more aggressive intervention for treatment of acute WAD patients.

Keywords: Whiplash injuries, Sling, McKenzie, Neck

서 론

2013년 경찰청 통계에 따르면 교통사고는 사고 215,354 건의 교통사고 에서 사망 5,092 명, 부상 328,711 명으로 교통사고로 인한 사망자보다 부상자가 차지하는 비율이 매우 높아 후유관리가 중요시되고 있다. 특히, 급성 편타성 손상(whiplash associated disorder, WAD) 환자는 만 성화 가능성이 높고 이 중 $44 \%$ 환자에서 2년 이상 경부통을 호소 하 는 것으로 나타났으며 $6 \%$ 환자들은 1년간 업무에 복귀하지 못했던 것으로 나타났다. 그러나 증상이 나타나는 시기에 차이가 있어서 어 떤 증상은 사고즉시 나타나기도 하고 어떤 증상은수 시간에서수 일 에 걸쳐 지연되어 나타나기도 한다. ${ }^{2}$ 이러한 이유로 편타성 손상은 신 경증 또는 소송에서의 유리한 입장을 노린 위병 등으로 무시되어 왔 으나 급성 경부통 환자인 편타성 손상 환자들은 경부의 근지구력, 고 유수용성감각, 관절가동범위에 변화를 보인다. ${ }^{3}$ 이로 인해 인건비를

Received Sep 20, 2016 Revised Oct 19, 2016

Accepted Nov 2, 2016

Corresponding author Dong-Woo Lee

E-mail Lee7810@honam.ac.kr
비롯하여 의료비, 장애, 업무 생산능력의 손실 등 이차적으로 소요되 는 비용이 상당히 많다. 그래서 Carroll 등은 증상을 정확하게 평가하 고 치료를 적용하는 것이 만성화를 방지하는 데 매우 중요하다고 보 고하였다.

급성 편타성 손상 환자에 대한 정확한 평가를 위해 교통사고 추돌 이후 자세에 대한 기전을 살펴보면 Lee 등의 연구결과에서 후방 추 돌 시 $30.3 \%$ 로 전상방 변위가 다수를 차지하였다고 보고하였으며, Cailliet은 인간의 평균머리 무게는 10-12파운드이지만 3인치 앞으로 머리가 위치하게 되면 무게는 30 파운드로 증가한다고 하였다. 경추 는 두개골과 체간을 연결해주는 7 개의 뼈와 디스크로 구성되어 있는 데 머리를 지지하고 안정성을 유지하는 기능을 수행하며 척추 중에 서 운동성이 가장 큰 관절을 이루고 있고 일상생활을 수행하는 데 있 어 머리의 안정화는 전신 균형과 협응의 조절이 기본이다.5,6 이러한 골격 정렬의 변화는 근육의 신장과 단축, 길항근과 주동근의 불균형 
같은 근육변화를 나타내어 목 위에 있는 머리가 교통사고로 인해 전 상방에 위치하게 된다면 기능 장애를 초래하게 되어 경부의 불안정 성이 나타난다.

이러한 불안정성에 대한 안정화를 위해서 슬링 운동치료는 흔들 리는 줄과 보조도구를 이용하여 환자가 능동적으로 치료에 참여할 수 있고 체중에 작용하는 중력을 감소시켜 조기에 치료와 운동을 시 작할 수 있는 운동치료의 한 접근법으로 제시되고 있다. ${ }^{8.9}$ 대근육은 다분절성 근육이라 할 수 있고, 몸에 가해지는 중력이나 무거운 물건 을 들어 올리는 등 외적 부하에 대해 균형을 유지하는 근육이며 소 근육은 단분절성 근육들로 척추만곡을 유지하며 척추의 전. 후방, 측방의 안정성을 유지하는 중요한 역할을 하는 긴장성 근육이다.10 슬링 운동치료는 손상되어 약화된 두경부의 심부 굴곡근인 긴장성 근육을 평가 및 재교육을 통하여 경부 안정화를 시킬 수 있다. 그렇기 에 급성기, 아급성기에서의 심부 굴곡 신전근의 안정을 위해서는 미 세한 움직임을 조절할 수 있는 슬링 운동치료를 통한 안정화 운동이 필요하다고 사료된다.

또한 경부 안정화를 위해서 멕켄지 운동은 경부의 자세 교정에 효 과가 있고 운동이 포함된 치료 프로그램이 환자의 기능을 향상시키 고 직장으로의 복귀율 증가 및 재발 감소에 영향을 미친다고 보고하 였다." 멕켄지의 치료 전략은 반복적인 운동을 이용한 환자의 자조적 인 치료, 운동, 가동운동, 도수교정, 환자교육이 있고, 경부통의 운동 방법은 7 가지 중에 4 가지의 신전 방법과 2 가지의 측방굴곡과 회전, 1 가지 굴곡 방법이 있다. 그 중 급성기에는 4 가지 운동법이 사용된다. ${ }^{12}$

지금까지 급성기에는 휴식을 권하였으나 최근에는 초기 손상 후 부드러운 목운동의 시작은 휴식과 진통제 또는 교육자료 및 칼라에 비해 더 효과적이라고 보고되었다. ${ }^{13}$ 현재 경부통에 관절가동술 ${ }^{3}$ 과 테이핑 등의 효과, 기능적인 자세의 변화를 통한 연구 ${ }^{14}$ 들은 많은 반 면, 두경부의 심부 굴곡근에 대한 운동으로 슬링을 이용한 운동을 두경부 무게를 조절하여 부드럽게 적용시킬 수 있음에도 불구하고 관련된 연구가 아직 미흡한 수준이다. 따라서 본 연구의 목적은 급성 편타성 손상 환자들에게 슬링과 멕켄지 운동을 적용하여 통증, 기능 장애수준, 관절 가동 범위에 미치는 영향을 비교하고자 한다.

\section{연구 방법}

\section{1. 연구대상}

본 연구의 대상자는 2015년 8월부터 사고일로부터 일주일 이내에 경 부 단순 방사선 촬영 검사를 실시하여 의사로부터 편타성 손상 진단 을 받고 광주광역시 C 한방병원에 내원한 환자들을 대상으로 모집 하였다. 본 연구에서는 대상자들을 모집공고문을 통해 모집하여 슬 링 운동군, 멕켄지 운동군, 대조군 세 군에 나누어 무작위로 각각 10
Table 1. General characteristics of subjects

\begin{tabular}{lccc}
\hline & $\begin{array}{c}\text { Sling group } \\
(n=10) \\
\text { Mean } \pm \text { SD }\end{array}$ & $\begin{array}{c}\text { McKenzie group } \\
(n=10) \\
\text { Mean } \pm S D\end{array}$ & $\begin{array}{c}\text { control group } \\
(n=10) \\
\text { Mean } \pm S D\end{array}$ \\
\hline Age (year) & $40.3 \pm 10.2$ & $41.5 \pm 12.0$ & $40.0 \pm 8.1$ \\
Height $(\mathrm{cm})$ & $162.3 \pm 9.5$ & $165.3 \pm 7.9$ & $166.5 \pm 8.6$ \\
Weight $(\mathrm{kg})$ & $57.4 \pm 12.1$ & $61.4 \pm 14.6$ & $65.6 \pm 12.5$ \\
\hline
\end{tabular}

명씩 배정하였다. 후방 추돌로 인한 교통사고 환자 중 본 연구의 목적 과 방법을 충분히 이해하고 연구에 참여하기로 동의한 30 명을 대상 으로 하였다. 영상 진단 시 뼈에 이상이 없고 연부조직 병변이 있는 자, 중추신경 또는 말초신경성 병변을 가진 자, 과거 전정기관의 병원 진단을 받은 자, 당뇨병 등 기저 질환이 있는 자, 고관절이나 무릎 발 목 관절의 병변이 있는 자, 경추에 골절이나 변형이 있는 자, 임신한 여 성, 정신장애나 본 연구에서 실시하는 실험동작을 이해하지 못하는 자는 본 연구에서 제외 하였다(Table 1).

\section{2. 실험방법}

\section{1) 실험설계}

(1) 운동프로그램

본 연구에서는 경부에 슬링을 적용한 운동법을 참고하여 본 연구의 목적에 맞게 굴곡과 신전에 관련된 부분을 수정하여 이완운동, 감각 신경 훈련, 안정화 운동법을 사용하였다. 멕켄지 운동은 경부의 7 가 지 운동 중 급성기 통증에 관련된 앉은 자세에서 머리 뒤로 당기기, 앉은 자세에서 머리 뒤로 젖히기, 바로 누운 자세에서 턱을 안으로 끌 어당기기, 바로 누운 자세에서 머리 뒤로 젖히기 네 가지 운동법을 정 적 최대 근력에서 7초간 지속하여 15-20회 반복 실시를 순차적으로 진행하였다. ${ }^{12}$ 운동 시 발생되는 통증에 대해 통증 변화와 대처 방법 에 대하여 설명하고 적용하였다. 운동 적용 기간은 주 3 회, 4 주간 시 행하였다.

(2) 일반치료

본 연구에서는 참여자들에 대한 일정한 도덕적 책임을 져야 하고 그 들의 권리를 보호해야 할 의무가 있다는 연구 윤리에 의해 모든 군에 기본적으로 일반치료를 시행하기로 하였다. 일반치료는 환자를 모집 한 C한방병원에서 기본적으로 시행되는 TENS (GP-400P, (주)굿플, 한 국)를 15 분씩 주 3 회, 4 주간 시행하였다.

\section{2) 측정방법 및 도구}

선정 조건에 부합한 대상자에게 구체적인 계획 및 방법을 알려준 후 동의한 자에 한하여 무작위로 세 그룹으로 나눈 뒤 사전검사를 통해 테이터를 획득한다. 그 후 4 주간 주 3 회 중재를 실시한다. 4 주간의 중 

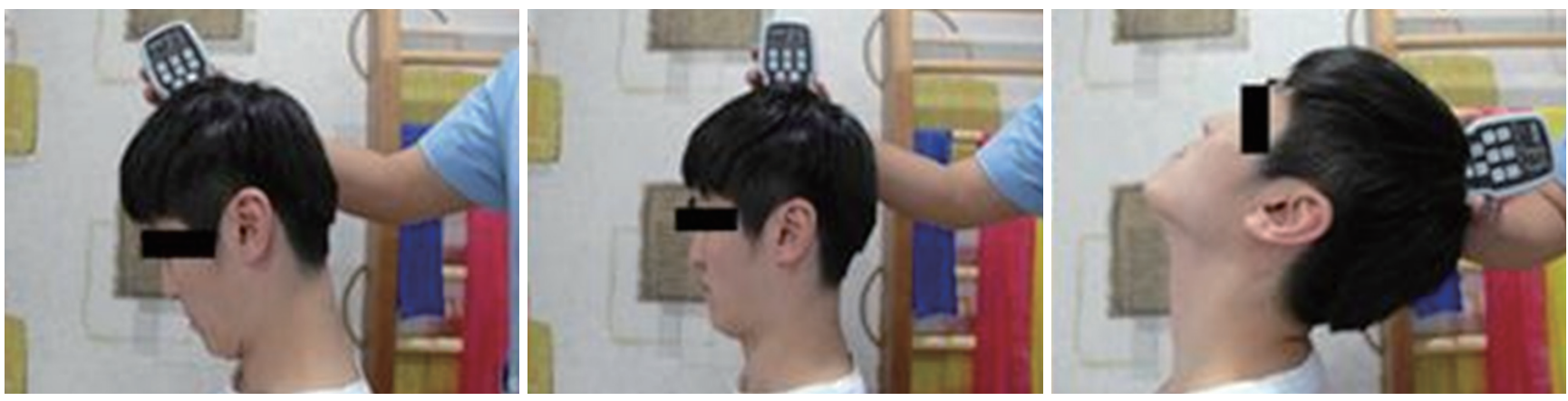

Figure 1. The picture of ROM test posture.

재를 마친 후 중재 전과 중재 후의 변화를 확인하기 위하여 사후 검 사를 실시한다. 단 연구의 일반화를 확보하고 측정자 간 오류와 측정 시 연구자의 의도를 배제하기 위해 모든 측정은 담당자 한명을 지정 하여 측정하고 그 담당자는 측정대상자가 어느 그룹인지 모른 채 측 정하였다.

통증의 수준을 평가하기 위해 시각적 상사 척도(visual analog scale, $\mathrm{VAS}$ )를 사용하였다. 시각적 상사 척도는 통증의 정도 측정에 가장 일 반적으로 사용되며 타당성이 있고 신뢰할만한 평가 도구이다. 자신 이 인식하는 통증 정도를 통증이 전혀 없는 상태인 $0 \mathrm{~cm}$ 에서 참을 수 없을 정도로 매우 극심한 통증인 $10 \mathrm{~cm}$ 까지 표현하였다. 통증 강도 평가는 $10 \mathrm{~cm}$ 의 눈금 선을 $1 \mathrm{~cm}$ 간격으로 표기한 평가지에 대상자가 자신의 통증 강도 또는 불쾌감에 해당된다고 생각하는 위치에 표시 하도록 하였다.

경부 장애지수(neck disability index, NDI) 설문지는 경추부 이상을 측정하는 가장 흔히 사용되는 설문약식으로 처음에는 심한 경부의 통증, 특히 편타성 손상 환자에서 일상생활의 제한점을 평가하기 위 하여 개발되었다. 경부의 통증을 가진 환자에게 스스로 장애를 평가 하기 위해 가장 널리 사용하며 가장 유효한 수단으로 입증된 NDI를 이용하여 측정하였다. 같은 영어권 국가일지라도 원본이 개발된 국가 와 적용되는 국가가 다른 문화를 가지고 있다면 문화적 차이를 고려 해 단어의 재선택이 필요하여 한국어로 번역된 NDI의 항목 ${ }^{15}$ 은 통증 의 강도, 개인 관리, 물건 들기, 책 읽기, 두통, 집중력, 일하기, 운전하 기, 수면, 여가활동 등에 관한 10 개의 항목으로 구성되어 있으며 각각 의 항목에는 6 개의 응답안이 있고 0 점에서 5 점까지 측정된다. 점수를 분석함에 있어서 0-4점은 장애 없음, 5-14점은 경도 장애, 25-34점은 중증장애, 35 점 이상은 완전 장애로 분류하였다.

경부 관절 가동범위 수준을 측정하기 위해 경추의 가동범위를 측 정할 수 있는 프로토콜이 내장되어 있고 본체 키패드를 이용한 빠른 계산 및 척추의 관절 가동범위 결과를 신뢰도 높은 측정값을 제공하 는 디지털 경사계(MicroFET5 ${ }^{\mathrm{TM}}$ Intelligent Inclinometer, Hoggan, 미국) 를 사용하였다. 대상자에게 측정을 위해 편안하게 의자에 앉은 채로
정면으로 시선을 응시하게 하고 총 3 회씩 반복하여 차이 값을 측정 한 후 평균값을 이용하여 통계분석을 시행하였다. 이 평가 방법은 급 간내 상관계수(ICC)가 0.96 으로서 높은 측정자 내 신뢰도(intrarater reliability)를 나타내었다(Figure 1).

\section{3. 자료분석}

각 항목에 대한 정규성 검정을 위해 샤피로 윌크 검정(Shapiro-wilk test)을 이용하였고 측정항목에 대한 각 그룹 내 중재 전. 후를 비교분 석하기 위해 대응표본 T 검정(paired sample t-test)을 실시하였다.

각 그룹 간 비교분석을 위하여 일원배치 분산분석(one-way ANO$\mathrm{VA}$ )을 실시하였고 사후검정은 터키 검정(Tukey Honestly significant difference test)을 실시하였다. 통계처리는 window version SPSS program 21.0 을 이용하였으며 모든 통계학적 유의수준은 $\alpha=0.05$ 로 설정하였다.

\section{결 과}

\section{1. 통증 수준 평가(visual analog scale, VAS)}

중재 전후에 따른 슬링 운동군, 멕켄지 운동군, 대조군의 통증 수준 평가는 세 그룹 모두 중재 전에 비해 중재 후에 통계학적으로 유의하 게 감소하였고 $(\mathrm{p}<0.05)$, 세 그룹의 중재 전후 통증 수준 평가의 변화 량 차이는 통계학적으로 유의한 차이가 있었다 $(\mathrm{p}<0.05)$ (Table 2). 사 후검정을 실시한 결과, 슬링 운동군과 대조군 사이에서만 통증 수준 평가의 변화량에 통계학적으로 유의한 차이가 있었다 $(\mathrm{p}<0.05)$ (Figure 2).

\section{2. 경부 장애지수(neck disability index, NDI) 설문지}

중재 전후에 따른 슬링 운동군, 멕켄지 운동군, 대조군의 NDI 설문지 점수 평가는 세 그룹 모두 중재 전에 비해 중재 후에 통계학적으로 유 의하게 감소하였고 $(\mathrm{p}<0.05)$, 세 그룹의 중재 전후 $\mathrm{NDI}$ 설문지 점수 평 가의 변화량 차이는 통계학적으로 유의한 차이가 있었다 $(\mathrm{p}<0.05)$ (Table 2). 사후검정을 실시한 결과, 슬링 운동군과 대조군 사이에서만 
Table 2. Comparison of outcome measures among groups at pre-post intervention

\begin{tabular}{|c|c|c|c|c|c|}
\hline & & SE group & McE group & Control group & $\mathrm{p}$ \\
\hline \multirow[t]{4}{*}{$\operatorname{VAS}(\mathrm{cm})$} & Pre-test (Mean \pm SD) & $4.90 \pm 0.87$ & $5.00 \pm 0.94$ & $4.90 \pm 0.87$ & 0.960 \\
\hline & Post-test (Mean \pm SD) & $1.80 \pm 1.47$ & $3.20 \pm 1.22$ & $3.60 \pm 1.35$ & $0.019^{*}$ \\
\hline & $\mathrm{t}$ & -7.154 & -4.070 & -3.074 & \\
\hline & $\mathrm{p}$ & $0.000^{* * *}$ & $0.003^{\star \star}$ & $0.013^{*}$ & \\
\hline \multirow[t]{4}{*}{ NDI (point) } & Pre-test (Mean \pm SD) & $13.90 \pm 3.81$ & $13.50 \pm 4.32$ & $13.20 \pm 2.65$ & 0.913 \\
\hline & Post-test (Mean \pm SD) & $4.60 \pm 1.50$ & $5.90 \pm 1.72$ & $8.50 \pm 1.90$ & $0.020^{*}$ \\
\hline & $\mathrm{t}$ & -8.333 & -5.491 & -7.421 & \\
\hline & $\mathrm{p}$ & $0.000^{* * *}$ & $0.000^{* * *}$ & $0.000^{* * *}$ & \\
\hline \multirow[t]{4}{*}{ Flexion $\left({ }^{\circ}\right)$} & Pre-test (Mean \pm SD) & $42.50 \pm 5.14$ & $42.40 \pm 3.95$ & $42.70 \pm 5.16$ & 0.990 \\
\hline & Post-test (Mean \pm SD) & $46.40 \pm 4.99$ & $44.20 \pm 3.76$ & $42.90 \pm 5.08$ & $0.032^{*}$ \\
\hline & $\mathrm{t}$ & 3.365 & 1.602 & 1.500 & \\
\hline & $\mathrm{p}$ & $0.008^{* *}$ & 0.114 & 0.168 & \\
\hline \multirow[t]{4}{*}{ Extension $\left(^{\circ}\right)$} & Pre-test (Mean \pm SD) & $62.20 \pm 7.94$ & $61.70 \pm 5.35$ & $61.20 \pm 6.12$ & 0.944 \\
\hline & Post-test (Mean \pm SD) & $67.80 \pm 4.31$ & $64.60 \pm 5.10$ & $61.60 \pm 5.89$ & $0.033^{*}$ \\
\hline & $\mathrm{t}$ & 3.025 & 2.211 & 1.309 & \\
\hline & $\mathrm{p}$ & $0.014^{*}$ & 0.054 & 0.223 & \\
\hline
\end{tabular}

SE: sling exercise, McE: McKenzie exercise, VAS: visual analog scale, NDI: neck disability index. ${ }^{*} p<0.05,{ }^{* *} p<0.01{ }^{* * *} p<0.001$.
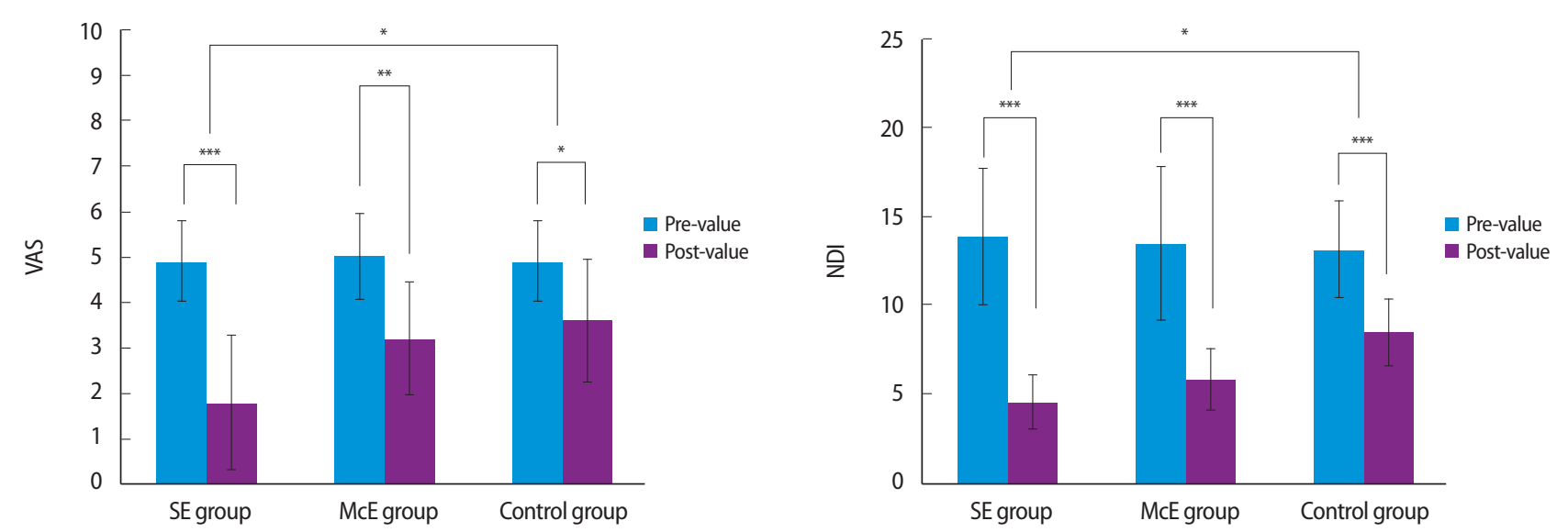

Figure 2. VAS \& NDI. SE group: sling exercise + TENS treatment, McE group: McKenzie exercise + TENS treatment, Control group: TENS treatment. ${ }^{*} p<0.05 ;{ }^{* *} p<0.01 ;{ }^{* * *} p<0.001$.

$\mathrm{NDI}$ 설문지 점수 평가의 변화량에 통계학적으로 유의한 차이가 있 었다 $(\mathrm{p}<0.05)$ (Figure 2).

\section{3. 관절가동범위(range of motion, ROM)}

1) 굴곡 가동범위 평가 비교

중재 전후에 따른 슬링 운동군, 멕켄지 운동군, 대조군의 굴곡 가동범 위 평가는 슬링 운동군에서만 통계학적으로 유의한 차이가 있었고 $(\mathrm{p}<0.05)$, 세 그룹의 중재 전후 굴곡 가동범위 평가의 변화량 차이는 통계학적으로 유의한 차이가 있었다 $(\mathrm{p}<0.05)$ (Table 2). 사후검정을 실 시한 결과, 슬링 운동군과 대조군 사이에서만 굴곡 가동범위 평가의 변화량에 통계학적으로 유의한 차이가 있었다 $(\mathrm{p}<0.05)$ (Figure 3).
2) 신전 가동범위 평가 비교

중재 전후에 따른 슬링 운동군, 멕켄지 운동군, 대조군의 신전 가동범 위 평가는 슬링 운동군에서만 통계학적으로 유의한 차이가 있었고 $(\mathrm{p}<0.05)$, 세 그룹의 중재 전후 신전 가동범위 평가의 변화량 차이는 통계학적으로 유의한 차이가 있었다 $(\mathrm{p}<0.05)($ Table 2). 사후검정을 실 시한 결과, 슬링 운동군과 대조군 사이에서만 신전 가동범위 평가의 변화량에 통계학적으로 유의한 차이가 있었다 $(\mathrm{p}<0.05)$ (Figure 3).

\section{고 찰}

교통사고 손상에 의한 급성 편타성 손상 발생 후 운동을 포함한 능 

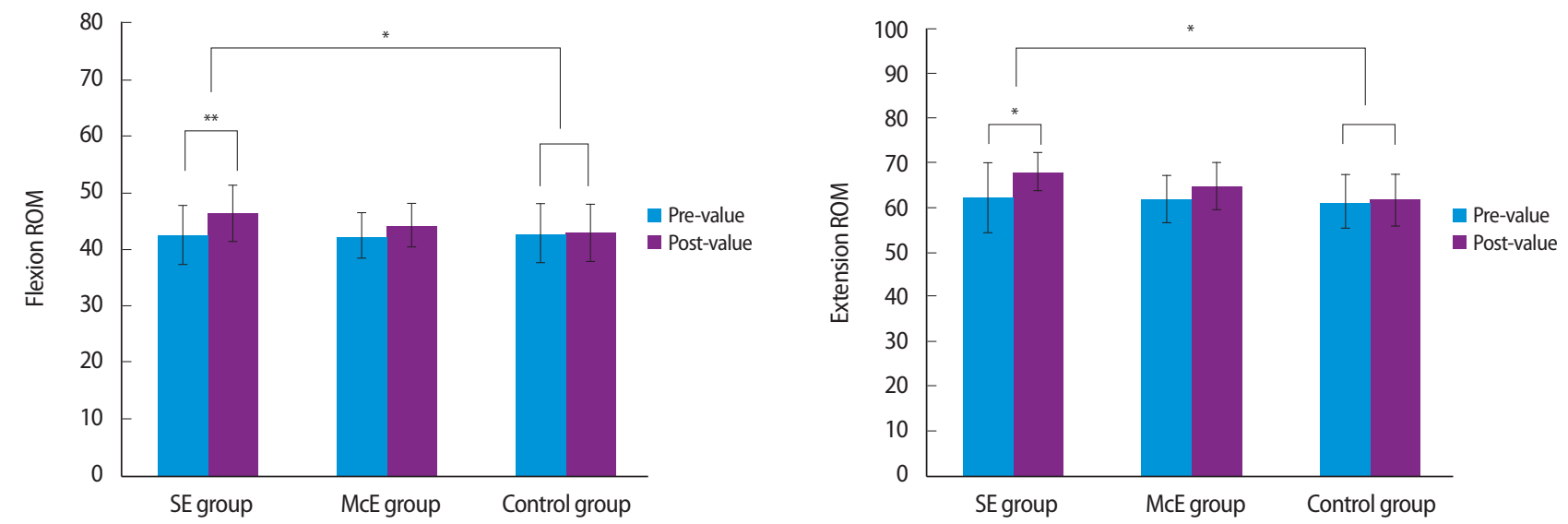

Figure 3. Flexion \& extension ROM. SE group: sling exercise + TENS treatment, McE group: McKenzie exercise + TENS treatment, Control group: TENS treatment.

${ }^{*} p<0.05 ;{ }^{* *} p<0.01 ;{ }^{* * *} p<0.001$

동적인 중재는 휴식, 부드러운 보호대와 같은 수동적인 치료보다 더 효과적이라고 하였다. 급성 경부통 환자의 부적절한 관리는 통증의 만성화를 가져오며 심리적 불안 및 생산성 결여로 이어져 사회적인 문제로 발전하게 된다. ${ }^{16}$ Carroll 등 ${ }^{4}$ 은 급성 편타성 손상 발생 직후에 수동적인 치료가 회복 속도를 느리게 하고 만성화시키는 데 연관되 어 있음을 보고하였다. 또한 교통사고 후 정신적인 고통에 도수치료 와 특수 운동치료 등의 물리치료 프로그램이 도움이 되며 통증과 기 능장애를 완화시키는 효과가 있다고 알려져 있다..$^{7}$ 경추부의 안정성 을 유지하는 것은 손상 예방과 치료적 완성도를 높이는 데 있어 매우 중요한 것이며, 최근에는 근육과 신경의 통합적인 관점이 더욱 강조 되어, 유연성, 협응성, 지구력, 근력을 향상시켜 척추 안정 근육들을 재조건화하는 총체적 운동의 필요성이 강조되고 있다. 관절 운동제 한은 한 관절뿐만 아니라 특정관절의 기능장애가 원인적 문제를 제 공하며 이와 상대적 길항관계에 있는 관절도 대상작용을 하여 관절 면 운동의 장애의 초래를 야기한다. 이에 다양한 재활프로그램을 적 용하여 관절 가동범위의 제한을 해소시키는 것이 무엇보다 중요하 다. 선행된 여러 연구에서도 경부통이 있는 사람들에서 경부 굴곡과 신전의 가동범위가 유의하게 증가된 것을 보고하고 있다.14,18-20

시각적 상사 척도인 VAS는 기존 연구에서 통증을 측정하는 데 있 어 신뢰도와 정확도가 높은 도구로 알려져 있으며 만성 통증에 비해 변이성이 높은 급성 통증도 측정하는 데 비율척도로서 높은 신뢰도 를 보여 왔다. 이를 이용하여 본 연구에서 시행한 슬링 운동과 멕켄지 운동이 통증에 미치는 효과를 검증한 결과 중재 전후에 따른 슬링 운동군, 멕켄지 운동군, 대조군의 통증 수준 평가는 세 그룹 모두 중 재 전에 비해 중재 후에 통계학적으로 유의하게 감소하였다 $(\mathrm{p}<0.05)$ 사후검정을 실시한 결과 슬링 운동군과 대조군 사이에서만 통증 수 준 평가의 변화량에 통계학적으로 유의한 차이가 있었다 $(\mathrm{p}<0.05)$. 본
연구에서도 슬링 운동과 멕켄지 운동이 능동적인 중재로써 경부 주 위의 근섬유의 길이변화, 근육 수축지연과 근 활동성의 억제와 같은 근육의 생리학적 개선을 촉진시켜 경부의 통증 감소에 긍정적 영향 을 미치는 것으로 보인다. 특히 슬링 운동군에서의 운동이 Park과 $\mathrm{Lee}^{21}$ 의 연구결과에서 경부 주위의 근력을 강화하는 운동을 하였을 때 통증이 감소된다고 하였으며, $\mathrm{Choi}^{20}$ 에 의하면 8주간의 경부 주변 근육의 근력강화 운동을 실시하였을 때 남자는 $5.43 \mathrm{~cm}$ 에서 $3.36 \mathrm{~cm}$ 로, 여자는 $5.44 \mathrm{~cm}$ 에서 $4.25 \mathrm{~cm}$ 로 감소하여 각각 $2.07 \mathrm{~cm}$ 과 $1.19 \mathrm{~cm}$ 정 도 통증이 감소되어 근력강화 운동이 통증감소에 효과가 있었음을 증명한 점에서 위의 선행연구들의 결과와 일치한다. 또한 멕켄지 운 동의 효과 역시 Kjellman과 Oberg 22 의 연구에서 77 명의 경부 통증환 자를 멕켄지 방법에 의한 자세교정 운동을 실시하고 12 개월 후에 재 조사한 결과 병원을 방문하는 비율이 멕켄지 방법을 이용한 자세교 정 운동군이 유의하게 적었다는 결과처럼 효과가 유의한 차이를 보 였다. 대조군에서의 유의한 통증 감소는 Park 등 23 이 지연성 근육통 을 보인 환자를 대상으로 TENS를 적용하여 실험 연구한 결과 각각 의 집단 내에서 통증의 변화가 통계학적으로 유의한 차이가 있었고, 본 연구에서 TENS를 시행한 대조군에서 통증과 기능장애 수준에서 의 유의성이 선행연구결과와 일치함을 보였다.

경부 장애지수 설문지인 NDI 설문지는 경부 통증 장애를 측정하 기 위해 여러 집단에서 널리 사용되어 왔으며 원래 편타성 손상과 관 련된 경부 통증으로 제한되는 일상생활의 활동정도를 평가할 목적 으로 개발되었다. 이에 본 연구에서 시행한 슬링 운동과 멕켄지 운동 이 기능장애에 미치는 효과를 검증한 결과 그에 관련된 NDI 설문지 점수 평가는 세 그룹 모두 중재 전에 비해 중재 후에 통계학적으로 유 의하게 감소하였다 $(\mathrm{p}<0.05)$. 사후검정을 실시한 결과 슬링 운동군과 대조군 사이에서만 NDI 설문지 점수 평가의 변화량에 통계학적으로 
유의한 차이가 있었다 $(\mathrm{p}<0.05)$. Choi와 $\mathrm{Kim}^{14}$ 의 선행연구에서 체간 의 기능적 자세를 통한 중력 부하상태에서 심부 굴곡근에 대한 운동 을 실시하였을 때 $\mathrm{NDI}$ 설문지 점수 평가는 중재 전 $9.35 \pm 2.01$ 에서 중 재 후 $2.74 \pm 1.84$ 로 유의한 감소를 보였다. 본 연구도 중재의 형태나 종 류는 다른 슬링 운동과 멕켄지 운동을 움직임을 통한 근육의 수축과 척추의 가동성을 주는 운동으로 보았을때 심부 굴곡근을 자극할 수 있다는 점에서 선행연구의 결과와 일치함을 보여준다. 대조군에서의 군내 비교 결과도 유의한 차이를 보여 시간이 지남에 따라 환자가 인 지하는 NDI 설문지 평가점수가 낮아짐을 가동범위의 결과로 조심스 럽게 유추해볼 수 있다. 본 연구에서 시행한 슬링 운동과 멕켄지 운 동이 굴곡과 신전 관절 가동범위에 미치는 효과를 검증한 결과 슬링 운동군에서만 통계학적으로 유의한 차이가 있었고 $(\mathrm{p}<0.05)$, 사후검 정을 실시한 결과 슬링 운동군과 대조군 사이에서만 굴곡과 신전 가 동범위 평가의 변화량에 통계학적으로 유의한차이가 있었다 $(\mathrm{p}<0.05)$. 이와 같은 결과로 실제 경부의 관절 가동범위가 증진된 것은 아니지 만 환자가 느끼는 NDI 설문지 평가점수는 시간의 차이에 따라 차이 가 있음을 짐작해볼 수 있다. $\mathrm{Kim}^{23}$ 의 선행연구에서 치료기간에 따 른 경추 가동범위에 있어서 멕켄지 운동군의 치료 전은 $60.84^{\circ}$ 였으며, 치료 후는 $62.26^{\circ}$ 로 통계적으로 유의하게 증가하였다. 하지만 본 연구 에서 시행한 멕켄지 운동이 관절 가동범위에 미치는 효과를 검증한 결과 중재 전후에 따른 멕켄지 운동군의 굴곡과 신전 가동범위 평가 는 중재 전후 통계학적으로 유의한 차이가 없었다. 이와 같이 선행연 구와 상반된 결과를 보여 $\mathrm{Kim}$ 등 $^{24}$ 의 연구인 경부 안정화 운동군과 자세교정 운동군인 멕켄지 운동과의 비교연구를 확인해본 결과 멕 켄지 운동군은 굴곡 $56.20 \pm 8.81^{\circ}$ 에서 $55.10 \pm 8.53^{\circ}$ 였고 신전 $62.40 \pm$ $11.09^{\circ}$ 에서 $62.20 \pm 12.02^{\circ}$ 로 굴곡과 신전 모두 유의성이 없었다는 또 다른 선행연구가 있었다. 이렇듯 선행 연구마다 결과의 차이가 있어 멕켄지 운동군의 관절 가동범위의 효과에 대해서는 더 많은 연구결 과와 논의가 필요할 것으로 보인다. 군간 차이에서 슬링 운동군과 대 조군 사이에서의 유의한 관절 가동 범위 증가는 고유수용성 감각 운 동이 두경부 굴곡 운동과 비교해 관절 위치 감각능력을 향상시키는 데 더 효과적이라고 알려져 있으므로 멕켄지 운동군에 비해 더 효과 적이라고 볼수 있을 것 같다.

실제 임상에서 근골격계 환자들의 근력강화 훈련 시 통증으로 인 한 근위축 및 근신경계 시스템의 운동조절 능력 및 근육 동원 능력이 저하되어 정확한 동작을 수행하기 어렵기에 멕켄지 운동은 자가운 동으로 시각적 지시와 구두적 지시가 없이 수행된 운동으로써 Bump 등 25 의 연구에서도 정확한 동작 수행에 있어 시각적 지시와 구두적 지시의 영향이 확인되어 한계점을 보였으며 Schega 등 26 의 연구에서 도 구두적 지시가 동작 수행 및 근육 동원에 긍정적인 효과가 있다고 보고된 것에 의하여 효과의 차이가 있었음을 추측해볼 수 있었다.
본 연구의 제한점은 한 지역의 병원에 내원한 환자들을 대상으로 하였기 때문에 연구 결과를 일반화하기에 한계가 있고 환자에게 동 일한 시간을 적용하였으나 운동 용량의 정확한 정량화가 어려웠다 는 점이다. 또한 목 통증으로 상지의 장애가 올 수 있으므로 치료계획 시 상지 운동을 포함시켜야 한다고 하였으나 ${ }^{27}$ 급성기임을 감안하여 경부에 운동을 국한시킨 설계적 제한점도 있다. 이런 여러가지 제한 점에도 본 연구에서는 급성기에 적용한 대조군과 유의한 차이를 보 인 슬링 운동치료의 통증, 기능장애수준, 관절 가동 범위에 미치는 영향은 휴식과 칼라만을 사용하기보다 또는 멕켄지 운동의 자가운 동보다 능동적인 중재를 적용시켜 볼 수 있는 하나의 접근 방법으로 써 제안하였고 후방 추돌로 인한 급성 편타성 손상 환자의 통증과 기 능을 개선시키고 만성이 되지 않게 예방하는 여러 방법 중의 하나로 써 임상에서 사용되길 바란다. 앞으로 연구는 제한점이 보완되고 급 성 편타성 손상환자에 대한 좀 더 다양한 운동접근법의 연구들이 필 요할 것으로 보인다.

\section{참고문헌}

1. Brison, RJ, Hartling L, Pickett W. A prospective study of acceleration-extension injuries following rear-end motor vehicle collisions. J. Musculoskelat. Pain. 2000;8(1-2):97-113.

2. Lee KY, Park MJ, Cho WY et al. Analysis about deviation of upper cervical of patients with whiplash injuries. The Acupuncture. 2003;20(6):2735.

3. Lee MH, Park RJ. The effect of MFR and taping on the pain level in whiplash injury. J Kor Phys Ther. 2004;16(3):125-41.

4. Carroll, LJ, Cassidy JD, Cote P. The role of pain coping strategies in prognosis after whiplash injury: passive coping predicts slowed recovery. Pain. 2006;124(1):18-26.

5. Chang JS, Lee JH. Comparison of cervical flexor muscles thickness during cranial-cervical flexor exercise according to pressure levels and eye directions in healthy subjects. J Kor Phys Ther. 2015;27(1):50-4.

6. Seo HJ, Kim JW, Son KK. The effect of different head positions with whole body vibration on muscle activation related to postural stability in standing. J Kor Phys Ther. 2014;26(3):156-62.

7. Park YN, Bae YS. Change of pain and breathing function following kinesio taping of myofascial pain in sternocleidomastoid muscle. J Kor Phys Ther. 2014;26(5):302-7.

8. Kim SY, Kim TY. Theoretical basis and application of the neurac technique which uses the sling exercise therapy. Korean J Orthop Manu Ther. 2006;12(2):52-65.

9. Yeom JN, Lim CG. Change of static and dynamic foot pressure after trunk stabilization exercises in children with spastic diplegic cerebral palsy. J Kor Phys Ther. 2014;26(4):274-9.

10. Lee WJ, Park S, Park JW. Influence of trunk stabilization exercise upon the lumbar stabilization and foot pressure in patients with back pain. J Kor Phys Ther. 2014;26(1):21-6.

11. Jung YW. Effects of McKenzie exercise on the functional recovery and 
forward head posture of chronic neck pain patients. J Korean Soc Phys Med. 2006;1(1);93-108.

12. McKenzie R. Treat your own neck. Waikanae New Zealand. Spinal Publications. 1983.

13. Spearing N, March L, Bellamy N et al. Management of acute musculoskeletal pain. APLAR J Rheum. 2005;8(1):5-15.

14. Choi HW, Kim SY. Research article: the effect of functional postural trunk exercise on pain, activities of daily living, range of motion, deep craniocervical flexor muscle endurance in neck pain patient by acute whiplashassociated disorders. J Korean Soc Phys Med. 2013;8(4):655-66.

15. Yoo SH, Ha HK, Lee HJ. Korean cultural adaptation of working alliance inventory and its reliability. J Kor Phys Ther. 2014;26(2):90-6.

16. Spitzer WO. Scientific monograph of the Quebec task force on whiplashassociated disorders: redefining 'whiplash' and its management. Spine. 1995;20(8):1S-73S.

17. Jull G, Sterling M, Kenardy J et al. Does the presence of sensory hypersensitivity influence outcomes of physical rehabilitation for chronic whiplash?-a preliminary RCT. Pain. 2007;129(1):28-34.

18. Dall'Alba PT, Sterling MM, Treleaven JM et al. Cervical range of motion discriminates between asymptomatic persons and those with whiplash. Spine. 2001;26(19):2090-4.

19. Lim HJ. The effects of joint mobilization on neck pain. Daegu University. Dissertation of Master's Degree. 2003.

20. Choi MH. The effects of cervical extension exercise for pain, range of motion and muscle strength on cervical extensor muscle injured patients. Korea University. Dissertation of Master's Degree. 2002.

21. Park HJ, Lee SN. The effect on the posture and neck pain in head backward. Journal of Sport and Leisure Studies. 2002;17:223-31.

22. Kjellman G, Oberg B. A randomized clinical trial comparing general exercise, McKenzie treatment and a control group in patients with neck pain. J Rehabil Med. 2002;34(4):183-90.

23. Park JM, Yang SH, Lee JY et al. The effect of TENS by physiotherapist versus home based TENS intervention to reduce pain and improve disability in patients with mechanical neck disorder. Korean J Orthop Manu Ther. 2010;16(2):61-6.

24. Kim SH, Kwon BA, Lee WH. Effects of cervical spinal stabilization training in private security on chronic neck pain and cervical function, neck pain, ROM. Korean Security Science Review. 2010;25(25):89-108.

25. Bump RC, Hurt WG, Fantl JA et al. Assessment of Kegel pelvic muscle exercise performance after brief verbal instruction. Am J Obstet Gynecol. 1991;165(2):322-9.

26. Schega L, Bertram D, Folsch C et al. The influence of visual feedback on the mental representation of gait in patients with THR: A new approach for an experimental rehabilitation strategy. Appl Psychophysiol Biofeedback. 2014;39(1):37-43.

27. Mclearn SM, Moffett JK, Sharp DM. An investigation to determine the association between neck pain and upper disability for paitents with nonspecific neck: a secondary analysis. Man Ther. 2011;16(5):434-9. 